\title{
The Effect of Risk-Based Capital on Investment Returns of Insurance Companies in Kenya
}

\section{ESJ Social Sciences}

\section{Willys Obuba Chache}

School of Business, University of Nairobi, Kenya

\section{Cyrus Iraya Mwangi}

School of Business, University of Nairobi, Kenya

\section{Winnie Nyamute}

School of Business, University of Nairobi, Kenya

\section{Caren Angima}

School of Business, University of Nairobi, Kenya

Submitted: 05 October 2020

Accepted: 10 November 2020

Published: 30 November 2020

Corresponding author:

Willys Chache

DOI: 10.19044/esj.2020.v16n31p111

(c) Copyright 2020 Willys Chache et al. Distributed under Creative Commons BY-NC-ND 4.0 OPEN ACCESS

\begin{abstract}
This paper focuses on analyzing the effect of risk-based capital on investment returns of insurance companies in Kenya. The study population comprised of 63 insurance companies licensed by Insurance Regulatory Authority (IRA). A longitudinal (panel) design was used to describe the association amongst variables on the study duration. Moreover, secondary data was collected from the insurance companies' annual returns submitted to IRA for five-year duration (2014-2018), which yielded adequate data points for each insurance company deeming it viable. Risk-based capital was determined by the standard formulae as per the risk-based supervision model. It was a composition of operational risk charge, market risk charge, insurance risk charge, credit risk capital charge, and an adjustment which considered the lossabsorbing capacity of technical provisions and deferred taxes. Investment returns in insurance companies was calculated using the investment income ratio. Test of normality, linearity, multicollinearity, and independence were conducted and were found suitable for linear regression to be conducted. Linear regression was used to evaluate the nature of the relationship between the variables based on the hypothesis in the study and at a significance level of 5\%. Coefficient of determination ( ) was derived to show how the model fits the data. The study findings revealed a positive and significant relationship between risk-based capital and investment returns, thus allowing investment portfolio managers in the insurance industry to justify their investments in high risk areas that may attract a high capital charge.
\end{abstract}


Subject: Business, Investments

Keywords: Risk-Based Capital, Investment Returns, Investment Income

Ratio, Linear regression analysis

\section{Introduction}

Risk-based capital (RBC) of any insurance or Reinsurance Company is used as a measure of guaranteed solvability in case of any financial distress (Kochanski, 2010). An insurance company should have enough capital to withstand any harsh economic condition. This has been addressed by the development of risk-based supervision framework which is expected to oversee that all insurers and reinsurers incorporate all the risks they encounter when determining the capital to hold. RBC is derived from capital charges imposed to specific risks an insurance company faces on its underwriting business and on its investment portfolio. This has an influence on insurance companies' asset management thus informing asset allocation and the expected investment returns (Johansen, 2011). Insurers recognize how important it is to separate investment management and the core insurance business because investment returns act as a backing for their reserves and capital. Thus, it is of significant importance in maximizing these returns (Smith, 1989).

Investment returns are a financial measure used to monitor performance of a business entity by analyzing the cost of investment, amount invested, and the benefits accumulated from the nature of investment (Preuss, 2016). Risk-based capital looks at the entire balance sheet where the risks facing both assets and liabilities of insurers are considered when determining the solvency position (Bragt et al., 2010). Insurance companies usually collect premiums from policy holders and create a pool of funds for claims payment and investments. The concept of RBC imposes capital charges to the nature and type of insurance business underwritten. Some classes under the insurance business are deemed high risk compared to others, thus attracting a high capital charge. This will have an impact on the insurance risk capital charge and on the overall risk-based capital. Capital charges are further imposed on various types of investments depending on the perceived risks on the selection of investments. RBC influences insurance companies' asset management, since some investments are deemed risk free based on the investment vehicle, and in turn may influence the investment returns of a company. Insurance companies reflect invested income in premiums quoted to policy holders, thus emphasizing the importance of separating the management of the insurance business and the management of their investments which back up their capital and their reserves (Smith, 1989). 


\section{Statement of the Problem}

Proliferation of sophisticated financial assets within the insurance industry has spawned the emergence of complex risk management models. The concept of risk-based capital was introduced in the insurance industry so that stakeholders of insurers can have an all-inclusive analysis of all risks an insurance company faces on both its assets and liabilities. This concept is important in assisting insurance companies to determine adequately their capital based on the size, nature, and complexity of their business. It retracts from the compliance-based approach of holding a fixed amount of capital to a more informed decision on capital available in accordance to the risk exposure of the company. Portfolio managers face a challenge of trying to make the best investment decision without attracting high capital charges, and at the same time quantifying the differences in risk adjusted returns resulting from investments in various asset classes and potential adjusting of insurance company's portfolios as per the risk-based capitals (Majtanova \& Marcinech, 2017).

The global financial crisis in the year 2008 raised serious questions on the stability of the insurance sector and effectiveness of financial regulations. One factor blamed as a potential source of this crisis was inadequate capitalization of companies to survive adverse crisis. Notably, most insurance companies tend to take greater risks by charging less premiums to attract more customers. This in turn has led to major losses thus affecting the capital available for the companies to operate efficiently (Afande \& Maina, 2015). The recent wave of corporate failures across the globe such as collapse of AIG, and more importantly local insurance companies such as Invesco Insurance (2008), Standard Assurance (2009), Stallion Insurance (2009), Blue shield Insurance (2011) and Concord Insurance (2013) despite holding the minimum capital requirement as per the insurance act, have been declared insolvent. These companies were placed under statutory management by the regulator, while some of them are under liquidation. Other companies issued profit warnings such as CIC Insurance (2016), Sanlam (2016/8), and Britam (2017/8). Thus, this is due to the impairment of financial assets covering corporate bonds and the general performance of the stock market. This has triggered increased government regulation to avert further collapses of these corporations. This has also led to the adoption of RBC, where risks are identified in a timely manner and capital is injected early enough to prevent a company from collapsing (Hogan, Meredith \& Pan, 2015).

The link between RBC and investment returns remains unclear due to divergence in findings. Mixed findings can be attributed to operationalization of study variables, selection of variables and control variables, and the choice of econometric models and contextual differences which give rise to conceptual, methodological, and contextual gaps. The choice of econometric 
model, study timeframe, and sampling issues are the major sources of contradicting findings in RBC-investor relationship. Different empirical studies have adopted distinct models such as internal models, standard approach models as well as VaR models. Looking at the various empirical studies, there are differences in methodological approach of RBC when determining the investment returns. Disputes arise in the suitability of the 99.5\% VaR in the model on the best estimate, minimum capital requirement, and risk margin. Scholars argue out that the proposed RBC model will have a deviation from the anticipated $99.5 \%$ confidence interval, thus not giving an assurance that the intended purpose will be met (Eling et al., 2007; Doff, 2008; Eling \& Pankoke, 2014).

At contextual level, institutional and cultural differences across countries where research was carried out is another possible explanation of divergence in findings. Some of these studies were undertaken in a European and American context, other studies were conducted in Asian nations. Furthermore, other studies were undertaken in an African context. The intracountries institutional differences partially explain the RBC-investor relationship inconclusive results. At the same time, it raises concern about whether the RBC-investor link which originated from industrialized countries is applicable in developing countries. Therefore, this gave rise to contextual gaps. Most studies, however, have been conducted in developed countries where RBC regulatory environment is different, and the results may not be generalized to a frontier market like Kenya. Furthermore, Lastra (2004) argues that developing countries differ widely among themselves based on sectorial or industry differences.

This study sought to answer the question: what is the effect of riskbased capital on investment returns of insurance companies in Kenya?

\section{Research Objective}

The study's objective was to determine the effect of risk-based capital on investment returns of insurance companies in Kenya.

\section{Literature Review \\ Theoretical Foundation}

Markowitz (1952) introduced the concept of modern portfolio theory (MPT) regarding portfolio selection to maximize returns. This theory focused on the rule that investors should maximize discounted anticipated returns. The approach means that the investor is considering the expected or anticipated return as what they desire and the variance of the return as an undesirable event, thus leading to the expected returns-variance of returns rule. It is expected that investors should fully diversify their portfolio to maximize anticipated returns. The law of large numbers is likely to ensure that the yield 
of the returns that is received is almost the same as the expected yield. The concept of risk-based capital is to have an overview of all the possible risks an insurance company might be facing holistically on the balance sheet (both assets and liabilities). This affects the investment returns either positively or negatively, since a company must select an investment portfolio which offers maximum returns. At the same time, it considers the risk charges, which in turn affect the risk-based capital. This study focuses on how risk-based capital affects investment returns of insurance firms in Kenya. The risk charge imposed by RBC on investments such as in the securities exchange affect the expected return on investment with asset allocation as a contributing factor, thus making this theory viable for the study.

Sklar's theorem was introduced by Sklar (1959) stating that a multivariate cumulative distribution can be expressed and broken down in terms of its marginal and a copula. The copula describes the dependence part of the distribution. Ruschendors (2009) further proved Sklar's theorem on the basis of distributional transformation of real random variables and its application. This process allowed for treatment of any general distributions, including the discrete parts, in the same manner as continuous distributions. The distributional transformation was further implemented in a stochastic ordering and it adequately defines the conditional value at risk measure. After successful implementation of the distributional transformation, the findings show that some consideration was not required on the discrete or mixed type distribution in comparison to the continuous distribution. This is in line with what is defined in Sklar's (1959) theorem. The concept of distributional transformation is currently applicable to risk measures. It is preferable in comparison to the conditional tail expectation (CTE), since CTE does not define coherent risk measure unless it is restricted to continuous distribution.

Using distributional transformation and defining the modified version as conditional value at risk, it allows one to use other distributions other than continuous distribution. The concept of RBC is used by the regulators to ensure that insurance companies are well capitalized and can survive the economic shocks that they may face in the future. This is the concept of stress testing of the company's balance sheet to create multiple what if scenarios thus being in tandem with the copula's theorem. Market risk capital charge, insurance risk capital charge, credit risk capital charge, and operational risk capital charge formulae adopted the copulas methodology. This risk charge was imposed while deriving the $\mathrm{RBC}$ as per the standard formulae. Through the aggregation of the risks, an insurance company can determine the capital allocation to cover the quantitative risks it may face (Tang \& Valdez, 2006). 


\section{Empirical Review}

The concept of RBC gives an overview of the entire risks an insurance company is facing on both its assets and liabilities side of the balance sheet. This affects the investment returns either positively or negatively (Eling \& Pankoke, 2014 a). Eling et al. (2007) outlined the approach in which the first pillar of RBS, which is the MCR and the RBC, was being developed. The researchers established that the methodology used is focused fully on the models which are already available. Despite it being evidential that models which are complex tend to be more successful, including aspects of dynamic cash-flow, it does not necessarily mean that complexity will yield value. The ultimate model choice should be reached at by considering the costs involved in development. Furthermore, it is suggested that future research should be done on how various solvency models can be used to measure financial distress. Their study did not look at the effect of RBC on investment returns of insurance companies.

Fare et al. (2004) looked at how profit efficiency in the banking industry is affected by risk-based capital. Their objective was to measure the profit efficiency using a new technique and also to see how risk-based capital affects this profit efficiency. The measure which was used concentrated on deviations from maximizing profits due to technical inefficiencies. These inefficiencies included failure in oversight by the managers and allocative inefficiencies caused by wrong inputs and outputs which are not optimal. The model used included both a risk weighted capital ratio and a leverage ratio, which led to the identification of how the constraints affect the banks' profits. The sampling was random for a period of three years for banks in the United States. Their findings confirmed that allocative inefficiencies are a major driver of profit or loss in comparison to technical inefficiencies, and that riskbased capital has a significant effect on the allocative inefficiencies. The study did not consider how risk-based capital specifically affects the investment returns.

Kochanski (2010) reviewed how RBC has an effect to unit linked products in the German insurance market. He argued that the defined RBC standard formulae only considered the traditional life insurance products and does not consider innovative life products. He further outlined the importance of lapse risk for innovative insurance products and gave out an alternative for calculating the net risk-based capital formulae. His findings show that the main risks that the German unit linked product faced were market risks and lapse risks, whereas mortality risk and expense risks were considered negligible. However, the study did not investigate how the new derived riskbased capital model will affect the investment returns of insurance companies.

Marlina and Puyarti (2013) conducted a study on how risk-based capital affects the profitability of a specific insurance company in Asia for a 
five-year duration. Risk-based capital was calculated as a ratio of the level of solvability and the minimum level of solvability. Their focus on profitability was on return on asset and return on equity. The methodology adopted was simple linear regression and Pearson correlation with a 95 percent confidence level. In their findings, risk-based capital explained about $29 \%$ variation on return on equity and $10 \%$ variation on return on assets. The study did not look at how risk-based capital would affect the entire industry but was specific on one insurance company.

Cheng and Weiss (2013) looked at the relationship between risk-based capital and a firm's risk taking in property liability insurance for a fifteen-year duration. The study made a comparison between pre and post risk-based supervision regulation on capital adequacy. The methodology used three stage least square estimation to investigate how risk-based capital relates with underwriting risk and asset risk. The research findings established that risk and capital are positively related, that is, when risk-based capital increases, there is also a significant increase in underwriting and asset risk prior to the adoption of risk-based supervision model. After introduction of RBS, both marginally and undercapitalized insurers increased their investment risk ratios and underwriting risk ratios. The study did not look at how risk-based capital informs investment decisions, and it in turn affects the investment returns of insurance companies.

Bett and Wepukhulu (2019) analyzed how insurance companies' performance is affected by the risk-based supervision model under the Kenyan context. The indicators used under the RBS model were capital adequacy, actuarial valuations, and growth in investments while considering the concentration limits set by the IRA. Financial performance was measured by the return on assets, return on capital employed, and earnings. The study incorporated all the insurance companies licensed by IRA. The study conducted the Pearson moment correlation analysis and later undertook multiple regression analysis by looking at the relationship between capital adequacy and performance, actuarial valuation and performance, and investments and financial performance. The study findings show that capital adequacy and investments affected financial performance in a positively significant manner, and that actuarial valuation had a negative significant effect on financial performance. The study would have been improved if it would have analyzed the computed risk-based capital and its effects on investment returns, looking specifically at income from investment and not underwriting profit.

\section{Conceptual Framework}

The study focused on the relationship between risk-based capital and investment returns of insurance companies. The dependent variable in the 
study was investment returns which was measured by the Investment Income Ratio over time. The independent variable in this study was risk-based capital which was determined from the principles of the RBC standard formulae and various risk capital charges per class of business as required by various regulations.

Figure 1. Conceptual model

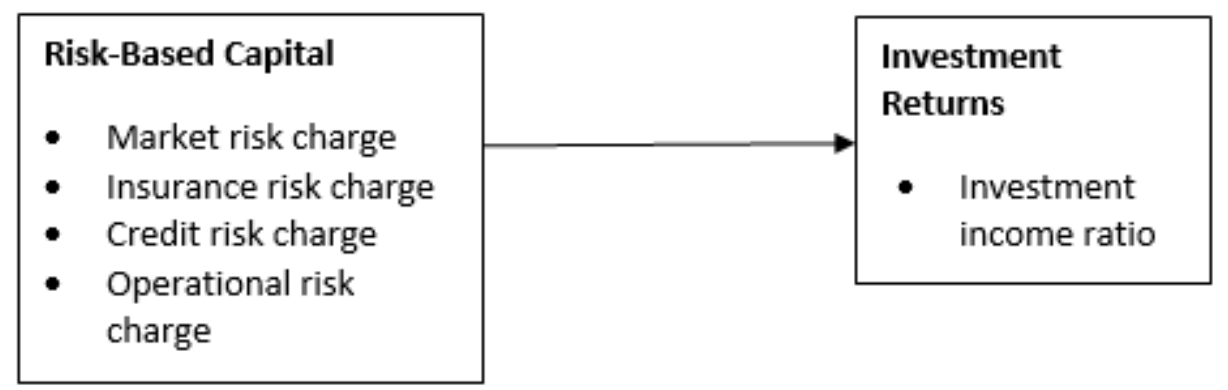

This study focuses on establishing the relationship between risk-based capital and investment returns. The null hypothesis that was tested in the study was as follows:

$\mathrm{H}_{1}$ : The effect of risk-based capital on investment returns of insurance companies in Kenya is not significant.

\section{Data and Methodology}

This study adopted a positivistic approach since it relied on evidence and sttistics to determine the relationship among variables. As suggested by Miller and Salkind (2002), positivism is an ideal approach to investigate the nature of relationships in empirical investigations that have hypotheses. A longitudinal (panel) design was adopted to describe the relationship between variables over time. Secondary data was collected from the insurance companies' annual returns submitted to IRA for five-year duration (20142018), which was adequate in computing the risk-based capital and the investment returns. For risk-based capital, data on market risk capital charge, insurance risk capital charge, credit risk capital charge, and operational risk capital charge was collected and used to compute the composite score. The investment income and earned premiums data was collected in order to compute the investment income ratio as an indicator of investment returns.

The five-year period yielded adequate data points for each insurance company deeming it viable. Diagnostic tests such as normality, homoscedasticity, multicollinearity, and independence test were conducted. Descriptive statistics were calculated with the aim of presenting the quantitative description of the data. Measures of central tendency (the arithmetic mean, mode and median) was calculated. Test of normality was 
conducted to ensure that the data is normal distributed and has homogeneity of variance. The relationship between the study variables, RBC and investment returns, was measured by correlation analysis. This established how suitable the data was for regression analysis to be performed. Linear regression was used to evaluate the nature of the relationship among various variables based on the hypothesis in the study and at a significance level of $5 \%$.

Risk-based capital was determined by the standard formulae as per RBS model. It was a composition of operational risk, market risk, insurance risk, credit risk capital charges, and an adjustment which considered the lossabsorbing capacity of technical provisions and deferred taxes. It was computed as follows:

$\mathrm{RBC}=\sqrt{\mathrm{IRC}^{2}+\mathrm{MRC}^{2}+\mathrm{CRC}^{2}}+$ Operational Risk. Equation 1

Under life insurance risk, other sub risk modules were calculated which included mortality risk, longevity risk, morbidity risk, expense risk, lapse risk, and catastrophe risk. Under general insurance risk, the risk sub modules calculated were premium reserves, claims reserves, lapse and catastrophe risks.

Investment returns in insurance companies was calculated using the investment income ratio. Thus, the ratio was calculated as follows:

General Insurance Companies:

Investment Income Ratio $=\frac{\text { Net Investment Income }}{\text { Net Earned Premium }}$ Equation 2

\section{Life Insurance Companies:}

Investment Income Ratio $=\frac{\text { Net Investment Income }}{\text { Life Fund }} \ldots \ldots \ldots . . .$. Equation 3

To determine the relationship between risk-based capital and investment returns, linear regression model on the panel data was used. The model that was used is as follows:

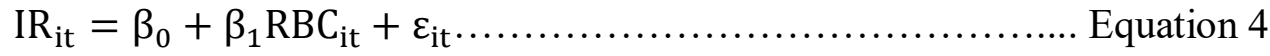

Where:

IR is the investment income ratio during the period,

$\mathrm{RBC}$ is the Risk-based capital,

$\beta_{0}$ : The regression constant, 
$\beta_{1}$ : The regression coefficient,

$\varepsilon_{\mathrm{i}}$ : is the random error term.

Adjusted $\mathrm{R}^{2}$ was used to assess the outcome variable variation as a result of effects of the predictor variable. F- Test was conducted to assess the model fit by testing the significance of the model. Beta coefficient $(\beta)$ showed the effect of variation in the dependent variable as result of a unit change in the predictor variable. T-test was used to evaluate the significance of the beta coefficient of the independent variable at $95 \%$ significance level.

\section{Results and Discussions}

A summary of descriptive analysis of the variables in the study is given in Table 1 below. Risk-based capital was calculated using the square root of the sum of squares of insurance risk capital charge, market risk capital charge credit risk capital charge, and operational risk capital charge. The results of the risk-based capital held are reflected in Table 1 below.

Table 1. Descriptive Statistics for Risk-Based Capital

\begin{tabular}{llll}
\hline Range (Kshs) & $\begin{array}{l}\text { Frequency } \\
\text { Firms) }\end{array}$ & (No of & Percentage (\%) \\
\hline Up to 250 Million & 17 & 27.0 \\
Over 250 up to 500 Million & 3 & 4.8 \\
Over 500 up to 1 Billion & 20 & 31.7 \\
Over 1Billion up to 2 Billion & 15 & 23.8 \\
Over 2 Billion up to 3 Billion & 3 & 4.8 \\
Over 3 Billion up to 4 Billion & 3 & 4.8 \\
Over 4 Billion & 2 & 3.2 \\
Total Firms & 63 & 100 \\
Arithmetic Mean (Kshs) & $1,041,247,909.204$ \\
Std. Deviation (Kshs) & $1,068,987,664.061$ \\
Coefficient of Variation (ratio) & 1.026 & \\
Minimum (Kshs) & $11,442,635.544$ & \\
Maximum (Kshs) & $5,068,523,892.93$ & \\
\hline
\end{tabular}

Source: Research Data

Most of the insurance companies (27\%) held a risk-based capital of up to 250 million, while $3.2 \%$ of the firms held a risk-based capital of over 4 billion. The average risk-based capital was 1.041 billion with a minimum of 11.4 million and a maximum of 5.06 billion on the 5 -year period average.

The result for investment returns which was measured by investment income ratio is shown in Table 2 below. Investment income ratio is used as one of the measures of profitability of an Insurance Firm which gives a reflection of an insurer's income purely from investment activities without 
incorporating operational income. Most of the insurance companies' investment income ratio ranges from -0.01 to 0.1 , which accounts for $31.75 \%$ of the total firms under study. About $11.11 \%$ of insurance company under study have an average investment income ratio of over 0.5 with the highest having an average of 3.10 during the study period.

Table 2. Descriptive Statistics for Investment Income Ratio

\begin{tabular}{lll}
\hline Range (Investment Income Ratio) & Frequency & Percentage (\%) \\
\hline$-0.01-0.05$ & 20 & 31.75 \\
$0.05-0.1$ & 9 & 14.29 \\
$0.11-0.2$ & 9 & 14.29 \\
$0.021-0.3$ & 10 & 15.87 \\
$0.031-0.4$ & 6 & 9.52 \\
$0.41-0.5$ & 2 & 3.17 \\
Above 0.5 & 7 & 11.11 \\
Total Firms & 63 & 100 \\
Arithmetic Mean (Ratio) & 0.302304 & \\
Std. Deviation (Ratio & 0.377479 & \\
Coefficient of Variation (Ratio) & 1.248674 & \\
Minimum (Ratio) & -0.225090 & \\
Maximum (Ratio) & 3.1027 & \\
\hline
\end{tabular}

Source: Research Data

\section{Diagnostic Tests}

Normality

The study conducted normality test using Shapiro-Wilk test. Table 3 below illustrates the findings of the test.

Table 3. Test of Normality

\begin{tabular}{llll}
\hline \multicolumn{3}{c}{ Shapiro-Wilk } & \\
\hline & Statistic & df & Sig. \\
RBC & .966 & 249 & .375 \\
Dependent Variable: Investment & & & \\
Returns & & & \\
a.Lilliefors Significance Correction & & & \\
\hline
\end{tabular}

Source: Research Data

Table 3 above shows p value $>0.05$ where $\mathrm{RBC}$ recorded a value of 0.375 thus indicating the data was normally distributed. 


\section{Linearity}

Linearity was tested using the Ramsey's RESET test as highlighted in Table 4 below. The table highlights that the variables have a significance level $>0.05$ thus indicating that linearity exists among the variables.

Table 4. Test for Linearity

\begin{tabular}{cccccc}
\hline \multirow{2}{*}{ Model } & \multicolumn{2}{c}{$\begin{array}{c}\text { Coefficients } \\
\text { Unstandardized } \\
\text { Coefficients }\end{array}$} & $\begin{array}{c}\text { Standardize } \\
\mathrm{d} \\
\text { Coefficients } \\
\text { Beta }\end{array}$ & $\mathrm{T}$ & Sig. \\
(Constant) & -20.323 & 17.118 & & -1.187 & .236 \\
RBC & 2.064 & 1.741 & 1.080 & 1.185 & .237 \\
ram1 & 26.963 & 18.443 & 2.811 & 1.462 & .145 \\
ram2 & -21.280 & 13.652 & -1.678 & -1.559 & .120 \\
& Dependent Variable: Investment Returns & \\
\hline \multicolumn{7}{c}{ Source: Research Data }
\end{tabular}

Source: Research Data

\section{Multicollinearity}

This study implemented the variance inflation factor (VIF) to determine whether multicollinearity exists amongst the variables. If a VIF value is less than 10, then the level of multicollinearity can be tolerated. The VIF for riskbased capital was 3.970 with a tolerance level of 0.2518 , thus indicating that the level of multicollinearity can be tolerated. This is shown in Table 5 below.

Table 5. Test of Multicollinearity

\begin{tabular}{lll} 
Variables & $\begin{array}{l}\text { Variance Inflation Factor } \\
\text { (VIF) }\end{array}$ & 1/VIF \\
\hline Risk-Based Capital & 3.970 & 0.2518
\end{tabular}
a. Dependent Variable: Investment Returns
Source: Research Data

\section{Independence Test}

This study adopted Durbin Watson test to confirm if the observations among the variables were independent. As per this test, the coefficient needs to be between 1.5 and 2.5 in order to confirm that the observations were independent. Table 6 below represents the independence test conducted in this study. 
Table 6. Independence test

\begin{tabular}{|c|c|c|c|c|}
\hline Variable & $\mathrm{R}^{2}$ & $\begin{array}{l}\text { Adjusted } \\
\mathrm{R}^{2}\end{array}$ & $\begin{array}{l}\text { S.E of the } \\
\text { Estimate }\end{array}$ & Durbin-Watson \\
\hline $\mathrm{RBC}$ & 0.474292 & 0.465494 & 0.625171 & 1.961820 \\
\hline $\begin{array}{l}\text { Investment } \\
\text { income ratio } \\
\text { a. Predictors: } \\
\text { b. Dependent } \\
\text { Source: Resea }\end{array}$ & $\begin{array}{l}0.507624 \\
\text { onstant), R } \\
\text { ariable: Inv } \\
\text { h Data }\end{array}$ & $\begin{array}{l}0.505614 \\
\text { nent Returns }\end{array}$ & 1.259701 & 2.000623 \\
\hline
\end{tabular}

From Table 6 above, the coefficient observed as per the DurbinWatson test for risk-based capital was 1.961820 and investment income ratio was 2. 000623. Since the coefficients lie between 1.5 and 2.5, it is an indication that the observations made were serially independent.

\section{Results and Discussion}

The study is focused on the establishment of the effect of risk-based capital on investment returns of insurance companies in Kenya. Panel data was used in establishing the investment returns which was measured by investment income ratio (net investment income/net earned premiums). Risk-based capital was calculated using the square root of the sum of squares of insurance risk capital charge, market risk capital charge credit risk capital charge, operational risk capital charge, and an adjustment which considered the lossabsorbing capacity of technical provisions and deferred taxes. The following hypothesis was developed:

Hypothesis 1: The effect of risk-based capital on investment returns of insurance companies in Kenya is not significant.

With investment returns as the dependent variable and risk-based capital as the independent variable, the results of the regression analysis are shown below in Table 7.

Table 7. Regression Analysis on Risk-Based Capital as the Independent Variable and Investment Returns as the Dependent Variable

\begin{tabular}{|c|c|c|c|c|c|}
\hline Model & $\mathbf{R}$ & $\mathbf{R}^{2}$ & Adjusted R $\mathbf{R}^{2}$ & \multicolumn{2}{|c|}{ S. E of the Estimate } \\
\hline $\begin{array}{l}\text { a. Predictors: } \\
\text { (Constant), } \\
\text { RBC }\end{array}$ & $.669 a$ & 0.447 & 0.445 & 0.05072 & \\
\hline Model & Sum of Squares & Df & Mean Square & $\mathrm{F}$ & Sig. \\
\hline Regression & 0.514 & 1 & 0.514 & 199.646 & $.000 \mathrm{~b}$ \\
\hline Residual & 0.635 & 247 & 0.003 & & \\
\hline Total & 1.149 & 248 & & & \\
\hline Model & \multicolumn{2}{|c|}{ Unstandardized Coefficients } & Standardized & $\mathrm{t}$ & Sig. \\
\hline (Constant) & $\begin{array}{l}\text { B } \\
0.231\end{array}$ & $\begin{array}{l}\text { Std. Error } \\
0.043\end{array}$ & Beta & 5.383 & 0 \\
\hline
\end{tabular}



RBC
0.069
0.005
0.669
14.13
0

a. Dependent Variable: Investment Returns

b. Predictors: (Constant), RBC

Table 7 above indicates an adjusted $R^{2}=0.445$, thus demonstrating that risk-based capital explains $44.5 \%$ of the variance in investment returns. From the model coefficients, the results indicate a statistically significant model since the $p$ value is 0.000 which is less than 0.05 level of significance. This finding therefore rejected the null hypothesis which implied that the effect of risk-based capital on investment returns of insurance companies in Kenya is significant. The regression model which explains the variation of the investment returns attributed to risk-based capital is shown below:

\section{$I_{\text {it }}=0.231+0.069 R_{B C} C_{i t}+\varepsilon_{i}$}

Where:

IR is the investment returns

$\mathrm{RBC}$ is the risk-based capital

\section{Summary and Conclusion}

The objective of the study was to determine the effect of risk-based capital on investment returns of insurance companies in Kenya. The study hypothesis show that the relationship between risk-based capital and investment returns was insignificant. The relationship between risk-based capital and investment returns was found to be significant thus leading to the rejection of the null hypothesis $\left(\mathrm{H}_{1}\right)$. The concept of risk-based capital is to ensure that all insurance companies are well capitalized in order to survive any harsh economic conditions. This means that insurers should hold assets in investments which can maximize their overall returns.

When determining the risk-based capital, capital charges are imposed on investments which are deemed risky while others attract a zero percent capital charge. Any insurer whose risk-based capital is high indicates that the firm is investing in highly volatile investments such as trading in the securities exchange or underwriting high volumes of premium. If an insurer invests in a high risk environment, it is expected that the return on investment would be high. At the same time, if a company underwrites more premium, it means it has more cash at hand for investments before claim payment. This explains why the relationship between risk-based capital and investment returns was found to be significant.

The above results are found to be consistent with previous empirical studies such as the study of Marlina and Puyarti (2013) which focused on how risk-based capital affect the profitability of some insurance companies in Asia 
by adopting a linear regression model with a Pearson correlation of $95 \%$ confidence level. The study findings alluded that RBC explained the variations on return on equity and return on assets. Bett and Wepukhulu (2019) analyzed how the risk-based supervision model affects the financial performance of insurance companies in Kenya whose choice of indicators were capital adequacy, actuarial valuation, and growth in investment under the quantitative pillar of RBS. The capital adequacy ratio was derived as a component of total capital available and the risk-based capital or minimum capital requirement.

The calculation of risk-based capital entailed operational risk charge, market risk charge, insurance risk charge, credit risk charge, and an adjustment which considered the loss-absorbing capacity of technical provisions and deferred taxes. The study finding shows that the capital adequacy had a positive significant effect on financial performance which is similar to the study findings. Waweru and Kisaka (2012) established that effective risk management had a positive influence on the value of the firm. These findings are in line with the current study findings which established that RBC has a positive influence on investment returns, which is a component of firms' value. However, the study findings were also contradictory to that of Koshanski (2010), which established that some of the risks, such as mortality risk and expense risk, were considered negligible when looking at how riskbased capital affects the performance of German unit linked products.

The rejection of the null hypothesis $\mathrm{H}_{1}$ as per the study findings established that there is a significant relationship between risk-based capital and investment returns of insurance companies in Kenya. This implied that the greater the risk-based capital, the higher the investment returns. This is a reflection that firms which invest in assets, which are deemed high risk by the regulator, tend to maximize their investment returns in comparison to the conservative firms who invest in zero or low capital charge investments (government securities) in order to hold a lower risk-based capital.

\section{Recommendations}

Due to a progressively complex financial service industry, all financial institutions are keen in managing their risks and holding enough capital in order to survive such crisis in the future. Most regulators in the insurance industry and banking sector across the globe have adopted risk-based supervision models, moving away from compliance-based capital requirements, and concentrating on a risk-based capital which is grounded on the size and complexity in operations of the financial institutions. This approach looks at both sides of the balance sheet (asset and liability) and imposes a percentage of capital charge to any investment or business operations as per a defined risk rating. The effect of risk-based capital on investment returns as illustrated in this study would help insurance companies' 
portfolio managers when defining investment policies. Thus, this will help determine the area to invest and the amount of risk-based capital the company will be obligatory to hold.

\section{References:}

1. Afande, F. O. \& Maina, P. M. (2015). Capital requirements for Kenyan life insurance companies. International Journal of African and Asian Studies, 8(2), 26-49.

2. Bett, L. K. \& Wepukhulu, J. M. (2019). Effect of adoption of riskbased supervision methodology on the performance of insurance companies in Kenya. International Journal of Business Management and Finance, 3(2), 139-165.

3. Bragt, D., Steehouwer, H., Waalwijik , B. \& Possen, T. (2010). Impact of the solvency II guidelines on asset liability matching for life insurers. Amsterdam: Ortec Finance Research Center.

4. Cheng, J. \& Weiss, M. (2013). Risk-based capital and firm risk taking in property-Liability insurance. The Geneva Papers on Risk and Insurance - Issues and Practice, 38(2), 274-307.

5. Doff, R. (2008). A critical analysis of the solvency II proposals. The Geneva papers, 33(1), 193-206.

6. Eling, M. \& Pankoke, D. (2014a). Systemic risk in the insurance sector: review and directions for future research. Risk Management and Insurance Review, 19(1), 249-284.

7. Eling, M., Schmeiser, H. \& Schmit, J. (2007). The solvency II process:Overview and critical analysis. Risk Management and Insurance Review, 10(1), 69-85.

8. Fare, R., Grosskopf, S. \& Weber, W. (2004). The effect of risk-based capital requirements on profit efficiency in banking. Applied Economics, 36(15), 1731-1743.

9. Hogan, T., Meredith, N. \& Pan, X. (2015). Risk-based capital regulation. Journal of financial regulation and compliance, 23(2), 115-134.

10. Johansen, T.K. (2011). A critical analysis of solvency II from a regulatory perspective. Unpublished PhD Thesis, Aarhus School of Business and Social Sciences.

11. Kochanski, M. (2010). Solvency capital requirement for German unit linked insurance products. German Risk and Insurance Review, 6(2), 33-70.

12. Lastra, R.M. (2004). Risk-based capital requirements and their impact upon the banking industry: Basel II and CAD III. Journal of financial regulation and compliance, 12(3), 225-239. 
13. Majtanova, A. \& Marcinech, P. (2017). Rebalancing of investment portfolios of insurers under solvency II. Economic Review, 46(1), 2544.

14. Markowitz, H. (1952). Portfolio selection theory. Journal of Finance, 7(1), 77-91.

15. Marlina, R. \& Puryati, D. (2013). The influence of risk-based capital to profitability in Jansindo Insurance Company. South East Asia Journal of Contemporary Business, Economics and Law, 2(1), 8-16.

16. Miller, D. \& Salkind, N. (2002). Handbook of research design \& social measurement. (6th ed.). Thousand Oaks, CA: Sage.

17. Preuss, M. (2016). Return on investment and grants: A review of present understandings and recommendations for change. Research Management Review, 21(1), 1-26.

18. Ruschendorf, L. (2009). On the distributional transform, Sklar's theorem, and the empirical copula process. Journal of Statistical Planning and Inference, 139(11), 3921-3927.

19. Sklar, A. (1959). Distribution functions with $\mathrm{n}$ dimensions and their margins. Publications of the Institute of Statistics of the University of Paris, 9(1), 229-231.

20. Smith, M. (1989). Investment returns and yields to holders of insurance. The Journal of Business, University of Chicago Press, 62(1), 81-98.

21. Tang, A. \& Valdez, E. (2006). Economic capital and the aggregation of risks using copulas. Sidney: University of South Wales.

22. Waweru, N. \& Kisaka, E. (2012). The effect of enterprise risk management implementation on the value of companies listed in the Nairobi stock exchange. International journal of business and commerce, 3(6), 1-17. 